\title{
STUDI POTENSI BIOGAS DARI SAMPAH DAUN PISANG MELALUI PENGURAIAN SECARA ANAEROBIK
}

\author{
Made Gunamantha ${ }^{1}$, Ni Wayan Yuningrat ${ }^{2}$ \\ 1,2 Jurusan Analis Kimia, Fakultas Matematika dan Ilmu Pengetahuan Alam \\ Universitas Pendidikan Ganesha \\ Singaraja, Indonesia
}

e-mail: md_gunamantha@yahoo.com,niwyuningrat@yahoo.com

\begin{abstract}
Abstrak
Penelitian ini dilakukan untuk mengetahui potensi produksi biogas dari sampah daun pisang dan karakteristik residu yang dihasilkan dalam potensinya sebagai pupuk. Daun pisang dipilih karena merupakan komponen sampah biorganik utama khususnya pada sampah yang ditimbulkan di wilayah perkotaan di Bali. Percobaan dilakukan melalui perlakuan awal terhadap substrat daun pisang.yang telah dikecilkan ukurannya. Perlakuan awal dilakukan dengan merendam substrat dalam larutan $\mathrm{NaOH} 0 \%, 0,25 \%, 0,75 \%, 1,25 \%$, dan $1,75 \%$ (selanjutnya dinyatakan sebagai P0, P1, P2, P3, dan P4) dengan rasio larutan/daun pisang (1 L:250 gr) selama 1 hari pada temperatur udara sekitar sebelum diinkubasi dalam digester yang telah diisikan inokulum. Hasil penelitian ini menunjukkan bahwa biogas yang dihasilkan sangat tergantung pada kondisi perlakuan awal. Produksi biogas komulatif dari masing-masing digester berturutturut untuk P0, P1, P2, P3, dan P4 adalah 1438, 2159, 2255, 2443, dan $2722 \mathrm{~mL}$. Adapun biogas yield (L/kg VS) yang dihasilkan dari masing-masing perlakuan berturut-turut untuk P0, P1, P2, P3, dan P4 adalah 146; 220; 229; 248; dan 277 L biogas per kilogram volatile solid (VS) substrat. Hasil penelitian ini menunjukkan bahwa dengan semakin meningkatnya konsentrasi $\mathrm{NaOH}$ yang diberikan dalam perlakuan awal, biogas yield yang dihasilkan juga semakin meningkat.
\end{abstract}

Kata kunci : sampah, daun pisang, lignin, biogas yield

\begin{abstract}
This study was conducted to determine the potential of biogas production from banana leaf litter and the characteristics of the resulting residue in its potential as a fertilizer. Banana leaves have been a major component biorganik garbage in garbage generated especially in urban areas in Bali. Experiments conducted through pretreatment of the substrate leaves pisang.yang been reduced in size. Initial treatment is done by immersing the substrate in a solution of $\mathrm{NaOH} 0 \%$, $0.25 \%, 0.75 \%, 1.25 \%$, and $1.75 \%$ (hereinafter referred to as $\mathrm{P} 0, \mathrm{P} 1, \mathrm{P} 2, \mathrm{P} 3$, and P4) with a weight ratio solution/banana leaf (2:1) for 1 day at ambient air temperature before it was incubated in the digester is loaded inoculum. The results of this study showed that the biogas produced is highly dependent on the pretreatment conditions. Cumulative biogas production from digester P0, P1, P2,
\end{abstract}


P3, and P4 were 1438, 2159, 2255, 2443, and $2722 \mathrm{~mL}$. The biogas yield resulting from each treatment or digester P0, P1, P2, P3, and P4 were 146; 220; 229; 248 , and $277 \mathrm{~L}$ of biogas per kilogram of volatile solids substrate ( $\mathrm{L} / \mathrm{kg} \mathrm{VS})$. The results of this study indicate that with the increasing concentration of $\mathrm{NaOH}$ were given in the initial treatment, the yield of biogas produced was also increasing. In terms of the quality of sludge generated in its potential as a fertilizer, the ratio $\mathrm{C} / \mathrm{N}$ in the sludge has met national standards of organic fertilizer. However, in the fluid part, the $\mathrm{C} / \mathrm{N}$ ratio did not met the national standard of organic fertilizers.

Keywords : garbage, banana leaf, lignin, biogas yield

\section{PENDAHULUAN}

Proses pengolahan secara anaerobik pada awalnya digunakan untuk mengolah limbah domestik dan kotoran hewan (Owen et al., 1979; Palmisano, 1996). Mengingat biogas yang dihasilkan dari proses penguraian secara anaerobik ini memiliki nilai kalor yang cukup tinggi ( $5000-5500 \mathrm{kcal} / \mathrm{kg})$, saat ini pemanfaatan proses ini telah berkembang luas seperti untuk pengolahan limbah industri dan limbah perkotaan termasuk sampah.

Terdapat beberapa faktor yang mempengaruhi rancangan dan kinerja proses penguraian secara anaerobik. Beberapa diantarnya berkaitan dengan karakteristik masukan sebagai substat, rancangan digester dan kondisi operasi (FAO, 1997; Iglesias et al., 2000; Zhang et al., 2007). Karakteristik fisik dan kimia substrat adalah informasi yang sangat penting untuk merancang dan mengoperasikan digester anaerobik karena mempengaruhi produksi biogas dan stabilitas proses selama penguraian secara anaerobik. Karakteristik tersebut meliputi tetapi tidak terbatas pada kandungan air, volatile solid, kandungan nutrien, ukuran partikel, dan biodegradabilitas (Buffiere et al., 2006). Biodegradabilitas menjadi penting terutama bila biomassa dari tanaman digunakan sebagai substrat dalam digester anaerobik seperti misalnya jerami padi, kulit kopi, fraksi organik sampah, dan limbah industri pertanian. Penguraian biomassabiomassa tersebut umumnya lambat dan memerlukan waktu yang lama di dalam digester. Hal ini terutama karena kandungan lignosellulosa yakni polimerpolimer yang resisten terhadap proses degradasi biologik dari bahan-bahan tersebut.

Lignosellulosa merupakan kompoen yang cukup besar dalam fraksi organik sampah. Lignosellulosa tersusun atas sellulosa, hemisellulosa, lignin, bahan-bahan ekstraktif dan beberapa bahan inorganik. Daun pisang memiliki kandungan lignin, sellulosa, dan hemisellulosa berturut-turut 24,3; 20,4; dan 32,1\% (Yadvika et al., 2004; Mohaputra et al., 2010). Sellulosa, hemisellulosa, dan lignin membentuk struktur yang disebut dengan mikrofibril yang memediasi stabilitas secara struktural sel tanaman (Rubin, 2008 in Mtui, 2009). Oleh karena itu, tidak seperti stark dan sukrosa yang dapat dibiodegradasi dengan mudah menjadi monosakarida, pemanfaatan bahanbahan legnosellulosik dalam proses biokonversi memerlukan pengolahan awal. Tujuan utama dari pengolahan 
awal ini adalah untuk merubah atau menyisihkan penghalang secara struktur dan komposisional untuk menghidrolisis dan dan dilanjutkan dengan tahapan penguraian berikutnya. Dalam hal ini adalah upaya untuk meningkatkan degistabilitinya, meningkatkan laju hidrolisis enzim, dan akhirnya meningkatkan hasil produk yang diinginkan (Hendriks and Zeeman, 2009).

Vacciano et al. (1987 dalam Taherzadeh et al., 2008) telah mempelajari pengaruh pengolahan awal dengan $\mathrm{SO}_{2}, \quad \mathrm{Na}_{2} \mathrm{CO}_{3}$, dan $\mathrm{NaOH}$ terhadap digistabilitas enzimatik pada kulit buah anggur. Hasil penelitiannya menunjukkan bahwa pengaruh degradasi terbesar diperoleh dari pengolahan awal dengan konsentrasi larutan $\mathrm{NaOH} 10 \%$ pada $120^{\circ} \mathrm{C}$. Neves et al. (2006) menggunakan $\mathrm{NaOH}$ sebagai alkali untuk melakukan pengolahan awal terhadap fraksi organik sampah (FOS) perkotaan. Ditegaskan bahwa pengolahan awal terhadap bahan-bahan yang mengandung lignosellulosik dapat meningkatkan biodegradabilitasnya.

Penelitian terkait yang memanfaatkan daun pisang belum dilakukan. Mengingat potensi limbah daun pisang di Bali cukup dominan dala komponen sampah, penelitian ini dilakukan dengan tujuan untuk mengetahui potensi produksi biogas dari sampah daun pisang yang diberikan perlakuan awal mengunakan larutan $\mathrm{NaOH}$.

\section{METODE \\ Penetapan Perangkat Percobaan}

Digester dibuat dari botol besar air mineral ukuran $17 \mathrm{~L}$. Volume kerja digester dirancang $10 \mathrm{~L}$. Sisanya $7 \mathrm{~L}$ pada bagian atas disediakan sebagai ruang untuk timbulan gas. Lima botol besar (selanjutnya disebut tabung A) digunakan dengan disediakan penutup dari rubber stopper pada bagian atasnya yang dilengkapi pipa penyalur gas. .Gas diukur dengan metode water displacement method dengan cara membalik botol plastik volume $1 \mathrm{~L}$ (selanjutnya disebut tabungl B). Setiap botol A dihubungan dengan botol B menggunakan selang plastik. Botol B diisikan dengan larutan $\mathrm{NaCl}$ jenuh agar biogas yang dihasilkan tidak larut di dalamnya. Biogas yang dihasilkan dari botol $A$ akan mengalir melalui selang ke botol B. Selanjutnya gas yang mengalir ke botol B akan menekan larutan dalam botol $B$ sehingga akan memindahkan larutan tersebut. Larutan yang dipindahkan ditampung dalam tabung $\mathrm{C}$. Banyaknya larutan yang dipindahkan inilah dipertimbangkan sebagai jumlah biogas yang dihasilkan (Gambar 1). 


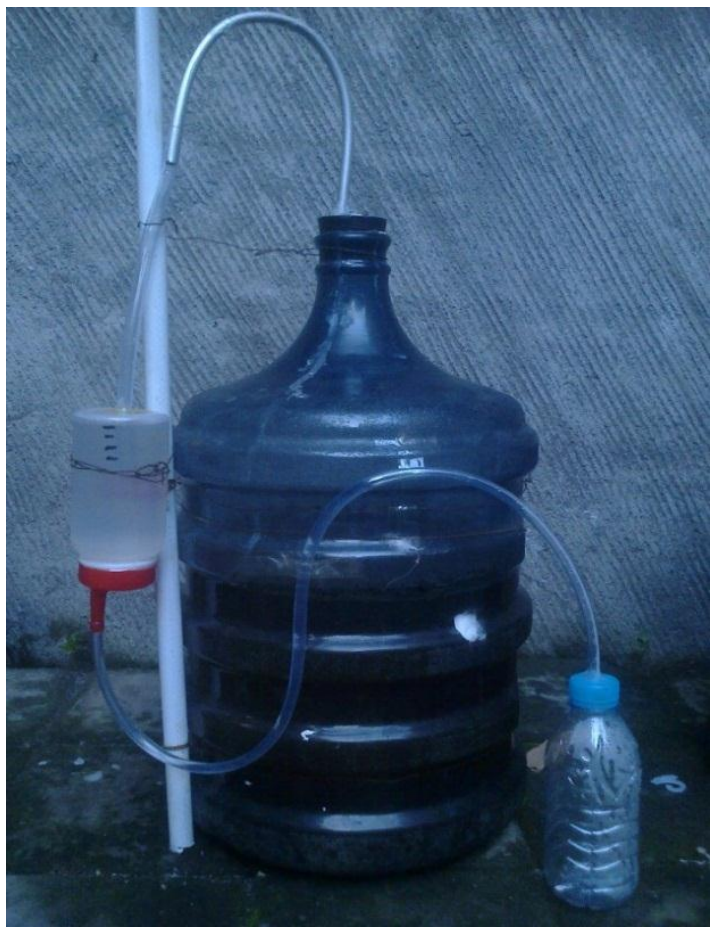

Gambar 1. Rangkaian Peralatan Percobaan.

\section{Langkah Percobaan}

1. Daun pisang yang telah dicacah untuk dijadikan umpan (substrat) disiapkan sebelumnya dan diberikan pengolahan awal.

2. Pengolahan awal terhadap daun pisang dilakukan dengan merendam daun pisang dalam larutan $\mathrm{NaOH} 0 \%$ (Blanko), 0,25\%, $0,75 \%, 1,25 \%$, dan $1,75 \%$ dengan rasio $250 \mathrm{gr}$ daun pisang dalam $1 \mathrm{~L}$ larutan $\mathrm{NaOH}$ selama 1 hari pada temperatur udara sekitar.

3. Digester dioperasikan dengan volume kerja yang sama untuk tanpa substrat (starter/inokulum saja), untuk substrat tanpa pengolahan awal dan untuk substrat yang diberikan pengolahan awal.
4. Inokulum yang telah disiapkan dimasukkkan ke dalam masingmasing digester sebanyak 30\% (3 $\mathrm{L})$ dari volume kerja digester $(17 \mathrm{~L})$.

5. Substrat daun pisang yang telah diberikan perlakuan awal dimasukkan ke dalam masingmasing digester dan ditambahkan dengan air bebas klor hingga volumenya mencapai $10 \mathrm{~L}$.

6. Digester yang hanya berisi starter ditambahkan air hingga volume kerja reaktor dan dinkubasi pada temperatur yang sama sebagai koreksi biogas yang dihasilkan dari satarter

7. Digester ditutup dengan rapat.

8. Digester diinkubasi selama 34 hari pada suhu udara sekitar.

9. Biogas yang dihasilkan diamati dari jumlah larutan yang dipindahkan dari tabung $\mathrm{B}$ ke tabung $\mathrm{C}$.

10. Bagian cairan dan sludge yang dihasilkan setelah 10 hari inkubasi dianalisis kandungan Total karbon organik dan nitrogennya.

\section{Metode Analisis Parameter- Parameter yang Diamati}

Untuk mengkarakterisasi sampah daun pisang dan mengevaluasi kinerja digester, beberapa parameter diukur dan ditentukan dengan mengikuti metode standar American of Public Health Association (APHA) dan American Standar for Testing Metterial (ASTM). Total solid (TS) dan Volatile Solid ditentukan dengan metode ASTM sedangkan Karbon Organik, dan Total Kjehdal Nitrogen (TKN) ditentukan menurut metode APHA. 


\section{HASIL DAN PEMBAHASAN}

Daun pisang yang digunakan dipotong secara manual menjadi partikel-partikel dengan ukuran 2-5 mm. Setelah dikeringkan di udara bebas, partikel-partikel daun diwadahi plastik gelap dan disimpan dalam lemari es menunggu untuk digunakan. Adapun inokulum yang digunakan dalam penelitian ini disiapkan dari kotoran sapi segar. Sebelum digunakan, inokulum diadaptasikan dulu dengan daun pisang pada kondisi anaerobik.
Hal ini dilakukan agar mikroorganisme dalam inokulum dapat menyesuaikan diri dengan substrat baru.

Penentuan karakteristik daun sebagai substrat dan inokulum dilakukan sebelum substrat dinkubasi. Parameter-parameter uji yang ditentukan meliputi ukuran partikel, kadar air, total solid (TS), volatile solid (VS), dan kandungan total karbon organik dan nitrogen. Tabel 1 menunjukkan karakteristik substrat daun pisang dan inokulum.

Tabel 1 Karakteristik Daun pisang dan Inokulum

\begin{tabular}{|l|c|}
\hline \multicolumn{1}{|c|}{ Bahan } & Nilai \\
\hline Partikel daun pisang & \\
\hline Ukuran partikel (mm) & $2-5$ \\
\hline Kandungan air (\%) & 68,96 \\
\hline TS (\%) & 31,04 \\
\hline VS (\%) & 88,71 \\
\hline Kandungan C dalam TS (basis kering) (\%) & 3,55 \\
\hline Kandungan N dalam TS (basis kering) (\%) & 0,78 \\
\hline Inokulum & \\
\hline TS (g/L) & 61,79 \\
\hline VS (g/L) & 99,84 \\
\hline Kandungan C dalam TS (basis kering) (\%) ppm & 0,19 \\
\hline Kandungan N dalam TS (basis kering) (\%) & 0,02 \\
\hline
\end{tabular}

Penguraian secara anaerobik adalah proses biologis di mana bahan organik biodegradable diurai dalam ketiadaan oksigen untuk menghasilkan biogas yang merupakan campuran dari gas $\mathrm{CH}_{4}(55-75 \%), \mathrm{CO}_{2}(25-45 \%)$, $\mathrm{H}_{2}(0-3 \%), \mathrm{N}_{2}(1-5 \%), \mathrm{CO}(0-0,3$ $\%), \mathrm{H}_{2} \mathrm{~S}(0,1-0,5)$, dan uap air ( dalam jumlah kecil ) ( Pauss et al.,1987). Bahan organik dapat terdegradasi melalui rangkaian tahapan proses hidrolitik, asidogenik, asetogenik, dan methanogenik untuk menghasilkan biogas. Meskipun, daun pisang memiliki kandungan selulosa tinggi tetapi juga mengandung lignin dan silika yang menghambat aktivitas mikroba untuk memproduksi biogas. Oleh karena itu, perlu dilakukan pengolahan awal terhadap daun pisang untuk memungkinkan selulosa menjadi lebih mudah diakses oleh mikroorganisme secara enzimatis. Dalam penelitian ini pengolahan awal dilakukan secara kimia dengan hidrolisis basa menggunakan $\mathrm{NaOH}$.

Beberapa faktor lain yang juga mempengaruhi adalah ketersediaan subtrat, dan inokulum. Substrat sedapat mungkin harus dikarakterisasi 
khususnya untuk komponen total padatan (TS) dan padatan mudah menguap (VS), karbon organik, total nitrogen, dan fosfor. Karakteristik lain yang penting adalah kandungan lignin, selulosa, dan hemiselulosa, khususnya substrat yang berasal dari turunan tanaman atau limbah pertanian. Karakterisasi terhadap komponenkomponen tersebut harus selalu dipertimbangkan karena keberadaan lignin yang tidak diuraikan akan berkontribusi terhadap potensi biogas yang dihasilkan oleh substrat (Buffière et al . 2006).

Tabel 1 menunjukkan bahwa ukuran partikel substrat daun pisang yang digunakan berkisar antara 2-5 mm.Ukuran partikel juga faktor penting yang mempengaruhi cepat lambatnya proses biodegradasi. Ukuran yang semakin kecil akan memiliki luas permukaan yang lebih besar sehingga akan lebih mudah diuraikan. Kadar padatan total (TS) dari substrat adalah $31,04 \%$ atau kadar airnya $68,96 \%$. Pada penguraian secara anaerobik kandungan padatan terlarut umumnya berada pada rentangan $5-10 \%$. Oleh karena itu dalam hal ini diperlukan penambahan air. Dalam penelitian ini massa subtrat yang digunakan pada masing-masing digester adalah $250 \mathrm{gr}$ dalam 7 liter air. Mengingat TS daun pisang adalah 31,04\% maka sebanyak $77,6 \mathrm{gr}$ berat kering daun atau 11,086 gr TS/L sebagai kondisi substrat awal dari masing-masing digester. Kadar VS partikel daun adalah $88,71 \%$ sehingga VS awal dari substrat dalam volume kerja digester adalah $9.834 \mathrm{~g} / \mathrm{L}$. Adapun kadar total karbon dan nitrogen pada bahan baku berturut-turut adalah 3,55 dan $0,78 \%$ (basis kering).
Ketersediaan

substrat berpengaruh secara signifikan dalam uji biometnanation potential (BMP) atau produksi gas karena mempengaruhi rasio antara permukaan dan volume untuk setiap partikel organik. Rasio ini sangat penting karena mikroorganisme hanya dapat mendegradasi zat pada permukaan padatan organik (Esposito et. al., 2012). Rasio substrat/inokulum (S/I) juga mempengaruhi kinerja uji BMP. Menurut Neves et . al (2004 dalam Esposito) rasio $\mathrm{S} / \mathrm{I}$ berkisar antara 0,5 dan 2,3 gVS/gVS dapat mencegah terjadinya pengasaman. Ketidakstabilan dalam proses anaerobik, seperti tingginya beban organik dalam effluent dan akumulasi asam lemak volatil dapat terjadi karena rasio S/I tidak sesuai (Suharso et. al., 2012). Feng et al. (2013) melaporkan, rasio S/l 1 menghasilkan gas yield tertinggi dan rasio S/I 6 menghasilkan biogas yield terendah. Berbeda dengan Feng, Suharso et al. (2012) melaporkan bahwa biogas yield tertinggi dihasilkan pada rasio $\mathrm{S} / \mathrm{l}$ pada rentangan 17,64 35,27. Namun demikian, kedua penelitian tersebut menggunakan jenis substrat dan inokulum yang berbeda. Dalam penelitian ini rasio $S / l$ yang digunakan adalah 0,45.

Pengolahan awal terhadap daun pisang dilakukan dengan merendam daun pisang dalam larutan $\mathrm{NaOH} 0 \%$ (Blanko), 0,25\%, 0,75\%, 1,25\%, dan $1,75 \%$. Hasil dari masing-masing perlakuan ini selanjutnya dimasukkan ke dalam digester berturut-turut diidentifikasi sebagai digester P0, P1, P2, P3, dan P4. Digester-digester tersebut diinkubasi selama 34 hari pada suhu sekitar. Produksi biogas dari masing-masing digester ditentukan 
dengan metode volumetrik, dalam hal ini menggunakan peralatan pemindah likuid (liquid displacement methods). Biogas dari reaktor yang masuk pada tabung yang berisi cairan selanjutnya memindahkan volume likuid dalam jumlah yang ekuivalen. Dalam upaya untuk mencegah biogas terlarut dalam air, larutan garam yang telah diasidifikasi disipakan dengan menambahkan $\mathrm{NaCl}$ ke air hingga larutan superjenuh terbentuk. Dua hingga tiga tetes asam sulfat pekat ditambahkan untuk mengasidifikasi larutan garam. Larutan yang telah terbentuk ini dimasukkan dalam tabung palstik $1000 \mathrm{~mL}$. Biogas yang mulai dihasilkan di dalam digester akan mengalir masuk mengisi tabung yang berisi larutan garam. Mengingat biogas tidak larut dalam larutan, kenaikan tekanan akan memberikan daya dorong untuk memindahkan larutan. Larutan yang dipindahkan diukur yang merepresentasikan jumlah biogas yang dihasilkan. Jumlah biogas ditentukan baik melalui volume larutan garam yang dipindahkan.

Selanjutnya biogas yang dihasilkan dihitung dengan mengurangkan biogas yang dihasilkan oleh inokulum dari biogas yang dihasilkan dalam uji dengan menggunakan subtrat daun pisang dan inokulum. Komulatif biogas yang dihasilkan dihitung sebagai jumlah biogas yang dihasilkan sepanjang periode inkubasi. Data produksi gas harian dan komulatif ditunjukkan pada Gambar 2.
Produksi biogas terhadap waktu dari digester P0, P1, P2, P3, dan P4 ditunjukkan pada Gambar 2. Substrat P0 (tanpa perlakuan awal) memerikan biogas yield yang terendah. Seperti ditunjukkan dalam Gambar 2, pada awal proses penguraian (dari hari kedua hingga keenam), dihasilkan 107, 141, 142, 130, dan $123 \mathrm{ml}$ biogas berturutturut pada hari ke-2, 3, 4, 5, dan 6 atau $643 \mathrm{~mL}$ biogas komulatif dihasilkan pada keseluruhan hari tersebut. Selanjutnya 4 hari tidak aktif dan baru aktif lagi pada hari ke-11 hingga ke-16. Aktivitas terhenti lagi hingga hari ke-20 dan aktif lagi pada hari ke-21 hingga ke25 sehingga komulatif biogas yang dihasilkan $2160 \mathrm{~mL}$. Aktifitas yang periodikal ini mungkin disebabkan oleh metanogen mengalami proses pertumbuhan methamorphik dengan mengkonsumsi prekursor metana yang dihasilkan dari aktifitas di awal proses. Sebagaimana yang dilaporkan oleh Deublein and Steinhauser, (2008), pada tahap awal dari keseluruhan proses produksi biogas, bakteri pembentuk asam menghasilkan asam lemak mudah menguap atau volatile fatty acid (VFA) yang mengakibatkan penurunan $\mathrm{pH}$ dan mengurangi pertumbuhan bakteri metanogenik dan methagogenesis. Artinya, pembentukan asam yang berakibat pada penurunan nilai $\mathrm{pH}$ berpengaruh terhadap inaktivasi dalam memproduksi biogas. Perubahan jumlah bakteri fermentasi dan metanogen serta $\mathrm{pH}$ juga dapat mengakibatkan perubahan produksi biogas harian hingga akhirnya tidak diproduksi biogas lagi (Soewarno, dkk., 2011). 


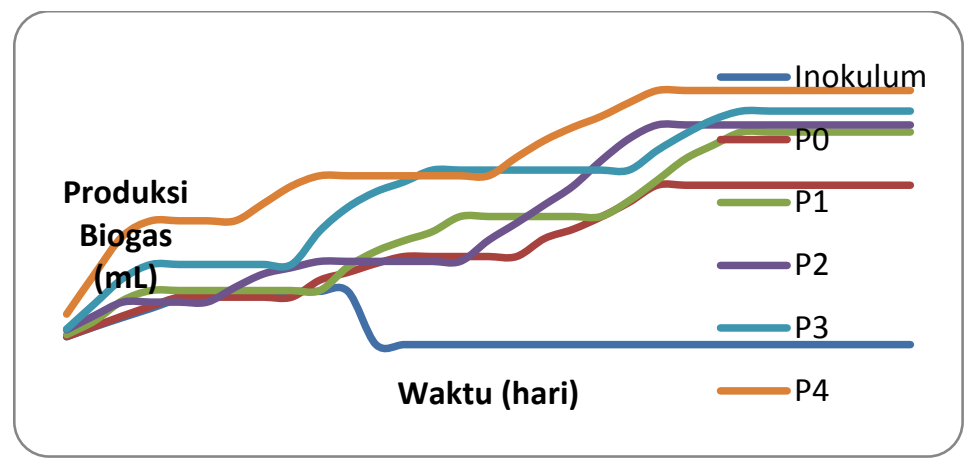

Gambar 2. Produksi Gas Harian dan Komulatif

Digester P1 dalam 4 hari pertama menunjukkan adanya produksi biogas. Pada hari ke- 6 hingga hari ke- 11 biogas tidak diproduksi. Pada hari ke-12 baru ada produksi lagi hingga hari ke18. Selanjutnya kembali mengalami masa inaktif hingga hari ke-23. Lamanya masa tidak aktif disebabkan oleh kandungan lignin yang masih tinggi dalam substrat. Produksi biogas terjadi lagi pada hari ke-24 hingga hari ke-28 kemudian mengalami periode tidak aktif lagi hingga hari ke 34. Digester P2 pada awal periode operasi (hari ke-2 hingga ke-4) menunjukkan adanya produksi biogas. Jumlah biogas yang dihasilkan pada hari ke-2, 3, dan 4 berturut-turut adalah $221 \mathrm{~mL}, 195 \mathrm{~mL}$, dan $180 \mathrm{~mL}$. selanjutnya mengalami fase inaktif hingga hari ke-7. Pada hari ke-8 hingga ke-11 biogas diproduksi lagi begitu selanjutnya mengalami fase inaktif lagi hingga hari ke-18. Pada periode berikutnya produksi biogas terjadi lagi yakni dari hari ke19 hingga hari ke-25 dan mengalami fase inaktif hingga hari terakhir pengamatan.. Dalam digester ini ditunjukkan bahwa waktu retensi substrat adalah $25-28$ hari. Keberadaan lignin sangat mempengaruhi waktu retensi substrat. Pada digester P3 diamati total produksi biogas $2543 \mathrm{~mL}$. Pola produksi biogas pada digester ini juga bersifat periodic. Selama 34 hari pengamatan, terdapat tiga periode produksi biogas yakani pada periode pertama dari hari ke-2 hingga ke-5, periode kedua dari hari ke11 hingga hari ke-17 dan periode ketiga dari hari ke-24 hingga ke-28. Volume komulatif biogas yang dihasilkan dari digester ini lebih tinggi daripada digester P2.

Sebagaimana pada digester yang sebelumnya, pada digester $\mathrm{P} 4$, produksi biogas juga terjadi secara periodik. Pada periode pertama biogas diproduksi dari hari ke-2 hingga hari ke5 selanjutnya mengalami fase inaktif hingga hari ke-8. Biogas diproduksi lagi pada hari ke-9 hingga hari ke-11 dan inaktif lagi hingga hari ke-19. Pada hari ke-20 biogas diproduksi lagi hingga hari ke-25 dan selanjutnya mengalami fase inaktif lagi hingga akhir pengamatan.

Penelitian ini menunjukkan bahwa biogas yang dihasilkan sangat tergantung pada karakteristik substrat. Mengingat kandungan lignin dan sellulosa yang masih tinggi pada substrat P0, maka produksi biogas kumulatif yang dihasilkan paling rendah. Produksi biogas komulatif dari masingmasing digester berturut-turut untuk P0, 
P1, P2, P3, dan P4 adalah 1438, 2159, 2255, 2443, dan $2722 \mathrm{~mL}$. Adapun biogas yield (L/g VS) yang dihasilkan dari masing-masing perlakuan atau digester berturut-turut untuk P0, P1, P2, P3, dan P4 adalah 0.146; 0,220; 0,229; 0,248; dan 0,277 L biogas per gram volatile solid (VS) substrat. Bila biogas yield dinyatakan dalam L/kg TS maka berturut-turut untuk P0, P1, P2, P3, dan P4 adalah 165, 248, 258, 280, dan 321 $\mathrm{L} / \mathrm{kg}$ TS. Hasil penelitian ini menunjukkan bahwa dengan semakin meningkatnya konsentrasi sodium hidroksida yang diberikan dalam perlakuan awal, biogas yield yang dihasilkan juga semakin meningkat. Hosseini et. al. (2011) melaporkan bahwa dengan meningkatnya konsentrasi sodium hidroksida dari 15 hingga $30 \mathrm{gr} / \mathrm{L}$ telah meningkatkan biodegradabilitas jerami padi sehingga meningkatkan biogas yang dihasilkan. Namun, penting untuk dicatat bahwa penggunaan $\mathrm{NaOH}$ yang terlalu banyak akan memberikan suasana basa pada substrat yang terlalu tinggi sehingga akan mempengaruhi aktifitas mikroorganisme.

Bila dibandingkan dengan hasilhasil penelitian sebelumnya yang dilakukan dengan tanpa pengolahan dari berbagai limbah biomassa memberikan biogas yield yang berbedabeda. Hasil-hasil penelitian tersebut ditunjukkan pada Tabel 2 berikut.

Tabel 2 Perbandingan dengan Hasil Penelitian Sebelumnya

\begin{tabular}{|c|c|c|c|c|}
\hline No. & Peneliti & Substrat & Biogas & Kondisi \\
\hline 1 & lyagba et.al (2009) & $\begin{array}{l}\text { Kotoran ternak } \\
\text { dan sekam padi }\end{array}$ & $\begin{array}{l}\text { 10,78 L/kg TS; } \\
13,49 \text { L/kg VS }\end{array}$ & $\begin{array}{l}\text { Temperature } \\
\text { kamar } 26-29^{\circ} \mathrm{C}\end{array}$ \\
\hline 2 & Kavitha (2007) & Limbah sayur & 391 L/kg VS & $\begin{array}{l}\text { Temperatur } \\
\text { kamar }\end{array}$ \\
\hline 3 & Lei et et.al (2010) & Jerami padi & $\begin{array}{l}280-300 \text { L/kg } \\
\text { TS; } 330-350 \\
\text { L/kg VS }\end{array}$ & $\begin{array}{l}\text { Temperatur } \\
\text { kamar }\end{array}$ \\
\hline 4 & Soewarno, dkk. & Sampah organik & $401 \mathrm{~L} / \mathrm{kg} \mathrm{TS}$ & $\begin{array}{l}\text { Pada suhu kama } \\
\text { (mesofilik) } 25- \\
30^{\circ} \mathrm{C}\end{array}$ \\
\hline 5 & $\begin{array}{l}\text { Anunputtikul and } \\
\text { Rodtong (2004) }\end{array}$ & Umbi singkong & 356,35 L/kg TS & \\
\hline 6 & $\begin{array}{l}\text { Bardiya et.al } \\
(1996)\end{array}$ & Kulit buah pisang & $231 \mathrm{~L} / \mathrm{kg} \mathrm{TS}$ & $\begin{array}{l}\text { Temperatur } \\
\text { kamar }\end{array}$ \\
\hline 7 & Kalia et. al (2000) & Batang pisang & $\begin{array}{l}267-271 \mathrm{~L} / \mathrm{kg} \\
\text { TS }\end{array}$ & Mesofilik \\
\hline
\end{tabular}

Walaupun tidak diberikan perlakuan awal terhadap bahan sumber substrat, beberapa substrat sebagaimana yang ditunjukkan dalam Tabel 4.5 memiliki potensi untuk menghasilkan biogas lebih besar dibandingkan dengan hasil penelitian ini. Hasil penelitian ini menunjukkan bahwa bila tanpa dilakukan pengolahan awal, biogas yield yang dihasilkan $165 \mathrm{~L} / \mathrm{Kg}$ 
TS. Kecuali bila dibandingkan dengan sekam padi, biogas yield yang diberikan jauh lebih rendah dibandingkan dengan substrat lainnya. Namun demikian setelah diberikan perlakuan awal, biogas yield yang dihasilkan dari daun pisang dapat mendekati substrat lainnya yang ditunjukkan pada Tabel 2. Hal ini menunjukkan tingginya kandungan lignin pada pada daun pisang. Mohapatra et al. (2010) melaporkan bahwa daun pisang memiliki kandungan lignin tertinggi (24,3\%) dibandingkan dengan bagian-bagian dari pohon pisang lainnya. Kenyataan ini menunjukkan bahwa daun pisang relatif kurang potensial untuk menghasilkan biogas demikian pula pengolahan awal dengan menggunakan $\mathrm{NaOH}$ juga kurang efektif dibandingkan dengan substrat lainnya yang tanpa pengolahan awal. Gambar 3 menunjukkan potensi biogas yield dari masing-masing perlakuan.

\section{Kualitas Sludge dan Cairan}

Sludge dan cairan adalah dua komponen utama yang dihasilkan dari proses penguraian secara anaerobik. Kandungan C-organik dan total Nitrogen adalah informasi penting untuk mengetahui potensi sludge dan cairan sisa hasil pengolahan secara anaerobik untuk dimanfaatkan sebagai pupuk. Kedua unsur tersebut merupakan unsur hara utama yang dibutuhkan oleh tanaman. Karbon organik merupakan salah satu yang diperlukan oleh tanaman dalam jumlah banyak dan berfungsi sebagai pembangun bahan organik. Adapun nitrogen berfungsi sebagai nutrient atau biostimulan. Hasil analisis kandungan karbon organik dan total nitrogen dan nilai $\mathrm{C} / \mathrm{N}$ dari sludge dan cairan ditunjukkan pada Gambar 4.

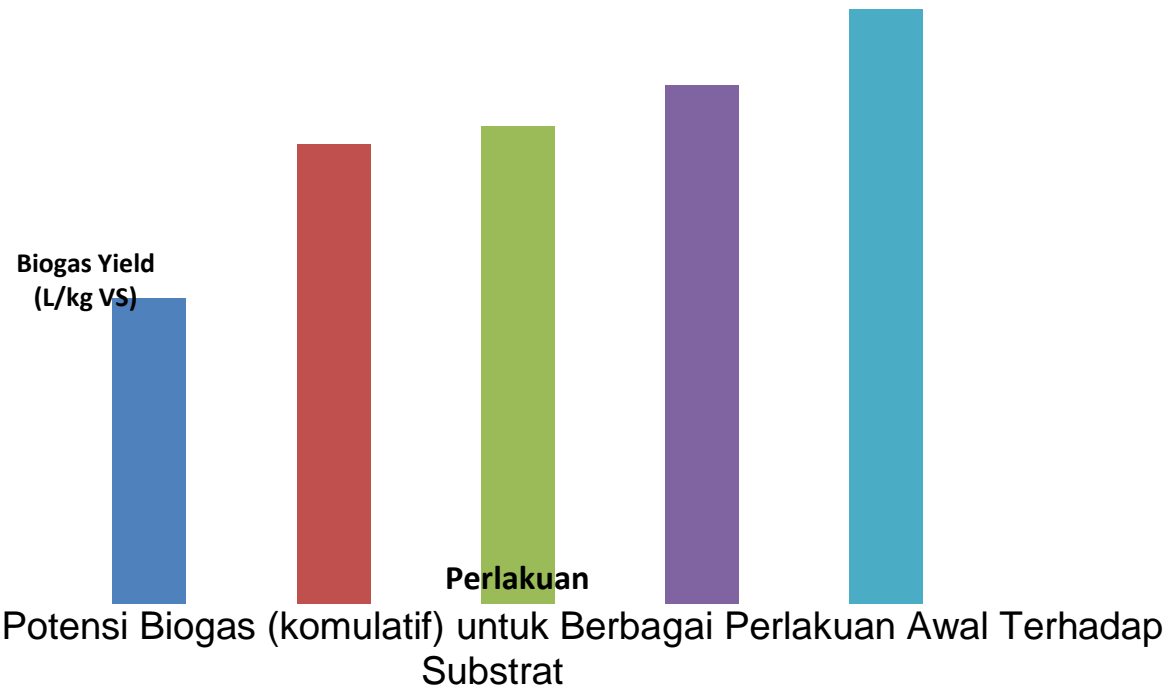

Gambar 3 Potensi Biogas (komulatif) untuk Berbagai Perlakuan Awal Terhadap Substrat 


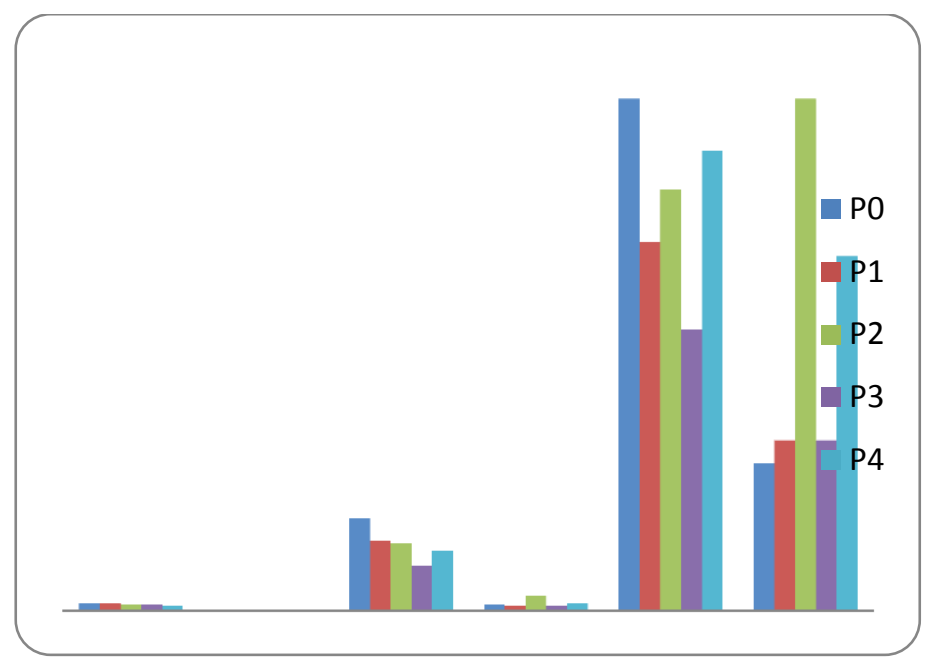

Gambar 4 Kualitas Sludge dan Cairan setelah Penguraian

Gambar 4 menunjukkan bahwa kandungan karbon organik dan $\mathrm{N}$ total dari masing-masing perlakuan bervariasi dari $1,14-2,34$ dan $0,13-$ 0,19 berturut-turut untuk kandungan $\mathrm{C}$ dan $\mathrm{N}$ pada bagian sludge. Demikian pula pada bagian cairan, kandungan $\mathrm{C}$ dan $\mathrm{N}$ otalnya bervariasi dari $0,13-$ 0,39 dan 0,04 -0,04 berturut-turut untuk kandungan $\mathrm{C}$ dan $\mathrm{N}$ total. Adapun rasio $\mathrm{C} / \mathrm{N}$ yang ditunjukkan pada masingmasing bagian adalah dari $7,13-13$ dan 3,75 - 13 berturut-turut untuk bagian sludge dan cairan. Menurut SNI 19-7030 tahun 2004 , standar rasio $\mathrm{C} / \mathrm{N}$ untuk pupuk cair organik adalah 11 20. Berdasarkan standar tersebut maka hanya satu perlakuan yang menunjukkan rasio $\mathrm{C} / \mathrm{N}$ pada bagian cairannya telah memenuhi standar tersebut. Pada sisi lain hampir semua perlakuan, rasio $\mathrm{C} / \mathrm{N}$ pada bagian sludgenya telah memenuhi standar tersebut. Perbedaan rasio $\mathrm{C} / \mathrm{N}$ pada bagian cairan dan sludge yang cukup lebar ini, menunjukkan bahwa substrat pada bagian cairan adalah yang diuraikan oleh mikroorganisme sedangkan pada bagian sludge merupakan sel-sel yang sudah mati atau sisa substrat yang tidak diuraikan. Pada kondisi anaerobik karbon organic tersebut telah diubah menjadi sel-sel mikroorganisme baru, karbondioksida, methan, dan gas lainnya dalam jumlah kecil.

\section{SIMPULAN DAN SARAN}

Penelitian ini menunjukkan bahwa biogas yang dihasilkan sangat tergantung pada karakteristik substrat. Mengingat kandungan lignin yang masih tinggi pada substrat P0, maka produksi biogas kumulatif yang dihasilkan paling rendah. Produksi biogas komulatif dari masing-masing digester berturut-turut untuk P0, P1, P2, P3, dan P4 adalah 1438, 2159, 2255, 2443, dan $2722 \mathrm{~mL}$. Adapun biogas yield (L/kg VS) yang dihasilkan dari masing-masing perlakuan atau digester berturut-turut untuk $\mathrm{P} 0, \mathrm{P} 1, \mathrm{P} 2, \mathrm{P} 3$, dan P4 adalah 146; 220; 229; 248; dan 277 $\mathrm{L}$ biogas per kilogram volatile solid (VS) 
substrat. Hasil penelitian ini menunjukkan bahwa dengan semakin meningkatnya konsentrasi $\mathrm{NaOH}$ yang diberikan dalam perlakuan awal, biogas yield yang dihasilkan juga semakin meningkat. Bila dilihat dari kualitas sludge yang dihasilkan dalam potensinya sebagai pupuk, rasio $\mathrm{C} / \mathrm{N}$ pada sludge telah memenuhi standar pupuk organik nasional. Namun tidak demikian halnya dengan bagian cairan. Rasio $\mathrm{C} / \mathrm{N}$ pada bagian ini tidak memenuhi standar pupuk organik nasional.

\section{DAFTAR PUSTAKA}

Anunputtikul, W and Rodtong, S. 2004. Laboratory Scale Experiments for Biogas Production from Cassava Tubers. The Joint International Conference on "Sustainable Energy and Environment (SEE. Hun-Hin Thailand.

Bardiya, N., Somayaji, D., and Khanna. 1996. Biomethanation of Banana Peel and Pineapple Waste. Bioresource Technology 58 (1996) $73-76$

Buffiere, P.; Loisel, D.; Bernet, N.; Delgenes, J.P. 2006. Towards New Indicators for The Prediction of Solid Waste Anaerobic Digestion Properties. Water Sci. Technol. 53, 233-241.

Deublein, D and Steinhauser, A. 2008. Biogas From Waste and Renewable Resources. WileyVch. Singapore

Esposito, G., Frunzo, L.,, Liotta, F., Panico, A., and Pirozzi, F. BioMethane Potential Tests To
Measure The Biogas Production From The Digestion and CoDigestion of Complex Organic Substrates. The Open Environmental Engineering Journal, 2012, 5, 1-8

FAO, 1997. Renewable Biological Systems for Alternative Sustainable Energy Production. FAO Agricultural Services Bulletin $-128$

Hendriks ATWM, Zeeman G. 2009. Pretreatments to Enhance The Digestibility of Lignocelluloses Biomass. Bioresour. Technol. doi:10.1016/j.biortech.2008.05.02 7. 100(1)10-18.

Hosseini S.M., Aziz, H.A., Meisam, S., Kiamahalleh $\quad 2011$. Optimization of $\mathrm{NaOH}$ thermochemical pretreatment for enhancing solubilisation of rice straw by Response Surface Methodology. 11th edition of the World Wide Workshop for Young Environmental Scientists (WWWYES-2011) - Urban Waters: resource or risks?, Arcueil : France

Iglesias, J.R., Pelaez, L.C., Maison, E.M., 2000. Biomethanization of municipal solid waste in a pilot plant. Water Research 34, 447454.

lyagba, E.T., Mengibo, I.A., Mohammad, Y.S. 2000. The study of cow dung as co-substrate with rice husk in biogas production. Scientific Research and Essay Vol.4 (9), pp. 861-866 
Kalia, V.C., Sonakya, V., and Raizada, N. 2000. Anaerobic Digestion of Banana Stem Waste. Bioresource Technology 73 (2000) 191-193

Kavitha, E.S dan Joshep, K. 2007. Biomethanation of Vegetable. Wastes. Journal of The IPHE India, Vol2007-08. No.3

Lei, Z., Chen, J., Zhang, Z., Sugiura, N. 2010. Methane production from rice straw with acclimated anaerobic sludge: Effect of phosphate supplementation. Bioresource Technology 101 (2010) 4343-4348

Mohaputra, D., Mushra, S., and Sutar, N. 2010. Banana and its byproduct utilization: an Overview. Journal of Scientific \& Inddustri Research. Vo. 69. 323-329.

Mtui, G.Y.S. 2009. Recent advances in pretreatment of lignocellulosic wastes and production of value added products. African Journal of Biotechnology Vol. 8 (8), pp. 1398-1415,

Neves, L.,Ribeiro, R., Oliveira, R., and Alves, M.M. 2006. Enhancement of Methane Production From Barley Waste. Biomass and Bioenergy 30, 599-603

Owen, W.F., Stuckey, D.C., Healy Jr., J.B., Young, L.Y., and McCarty, P.L. 1979. Bioassay for monitoring biochemical methane potential and anaerobic toxicity, Water Resour., vol. 13, pp. 485492

Palmisano, A,C; Barlaz,M,A. 1996. Microbiology of Solid waste. Florida. CRC Press. Inc
Pauss, A., Naveau, H., and Nyns, E.J. 1987. Biogas Production. In: Biomass (eds. Hall, D.O. \& Overend, R.P.) pp. 273-291. A Wiley-Interscience Publication, New York.

Soewarno, N., Sato, A., and Muchayat. 2009. Pengolahan Sampah Organik untuk Memproduksi Biogas Sebagai Sumber Energi Terbarukan. 2009. Prosiding Seminar Nasional Teknik Kimia Indonesia-STNKI 2009. Institut Teknologi Bandung. Bandung.

Sunarso, Johari, Widiasa, I.N., and Budiyono. The Effect of Feed to Inoculums Ratio on Biogas Production Rate from Cattle Manure Using Rumen Fluid as Inoculums. Internat. J. of Waste Resources, Vol. 2(1):1-4.

Taherzadeh, M.J and Karimi, K. 2008. Pretreatment of Lignocellulosic Wastes to Improve Ethanol and Biogas Production: A Review. International Journal of Molecular Sciences. 9, 1621-1651

Yadvika., Santosh., Sreekrishnan., T.R., Kohli, S., and Rana, V. 2004. Enhancement of Biogas Production from Solid Substrates Using Different Techniques-a review. Bioresource Technology XxX (2004) XXX-XXX. Science direct. Elsevier.

Zhang R., El-Mashad, H.M., Hartman, K., and Wang F. 2007. Characterization of food waste as feedstock for anaerobic digestion. Bioresource Technology 98, 929935.

Jurnal Sains dan Teknologi|323 